\title{
Modeling the Effect of Increased Sediment Loading on Bed Elevations of the Lower Missouri River
}

by John Shelley

PURPOSE: This US Army Corps of Engineers (USACE) National Regional Sediment Management Technical Note (RSM-TN) documents the effects of increased sediment loading to the Missouri River on bed elevations in the lower 498 miles. This was accomplished using a onedimensional (1D) HEC-RAS 5.0.7 sediment model.

INTRODUCTION: The seven mainstem Missouri River dams trap tremendous volumes of sand per year. The most downstream dam, Gavin's Point Dam, annually traps between 3.8 and 4.9 million $\mathrm{yd}^{3 *}$ of sand (USACE 2013). Meanwhile, the channel bed downstream has degraded significantly due to lack of sediment. This sediment-starved condition has led to a loss of sandbar habitat crucial for threatened and endangered species (USFWS 2000; USFWS 2003). USACE (2013) analyzes several prescribed scenarios for flushing sediment from Gavin's Point Dam to the downstream Missouri River. Analyses in progress are assessing reservoir dredging with discharge of the sediments to the downstream channel and flushing in combination with dam retrofits to install lower-level flushing gates.

The river immediately below Gavin's Point Dam (River Mile [RM] 811) has degraded significantly since dam closure. The Lower Missouri River, defined as the lower 498 RM running from Rulo, Nebraska, to the confluence with the Mississippi River at St. Louis Missouri, has also experienced significant degradation (USACE 2017). The most pronounced of this degradation, centered in the Kansas City metro area, derives principally from in-channel sand mining and floodplain deposition of sands during major floods (USACE 2017) and did not begin until the flood of 1993 and the subsequent channel mining increases through the 1990s and early 2000s. However, these activities and processes occur in the context of an overall sediment-starved river.

This RSM-TN assesses the physical effect of increased sediment loads at Rulo, Nebraska, on bed elevations in the Lower Missouri River from RM 490 to RM 0. The first section summarizes the 1D sediment model used in this analysis, the second section provides the results, and the third section discusses the implications.

NUMERICAL MODEL: USACE (2018a) describes the creation, parameterization, and calibration of 1D HEC-RAS 5.03 mobile-bed sediment model used to assess habitat alternatives for the Missouri River Recovery Program (MRRP). Summary descriptions and figures from that document are included here. Figure 1 provides a schematic of the model network with river miles, major tributaries, channel cross-sections, and US Geological Survey (USGS) gages located. Due to the length of the river modeled, a detailed mapping of all pertinent features including levees, floodwalls, and river training structures for the full $498 \mathrm{RM}$ is not provided here.

\footnotetext{
${ }^{*}$ For a full list of the spelled-out forms of the units of measure used in this document, please refer to US Government Publishing Office Style Manual, 31st ed. (Washington, DC: US Government Publishing Office 2016), 248-52, https://www.govinfo.gov/content/pkg/GPO-STYLEMANUAL-2016/pdf/GPO-STYLEMANUAL-2016.pdf.
} 


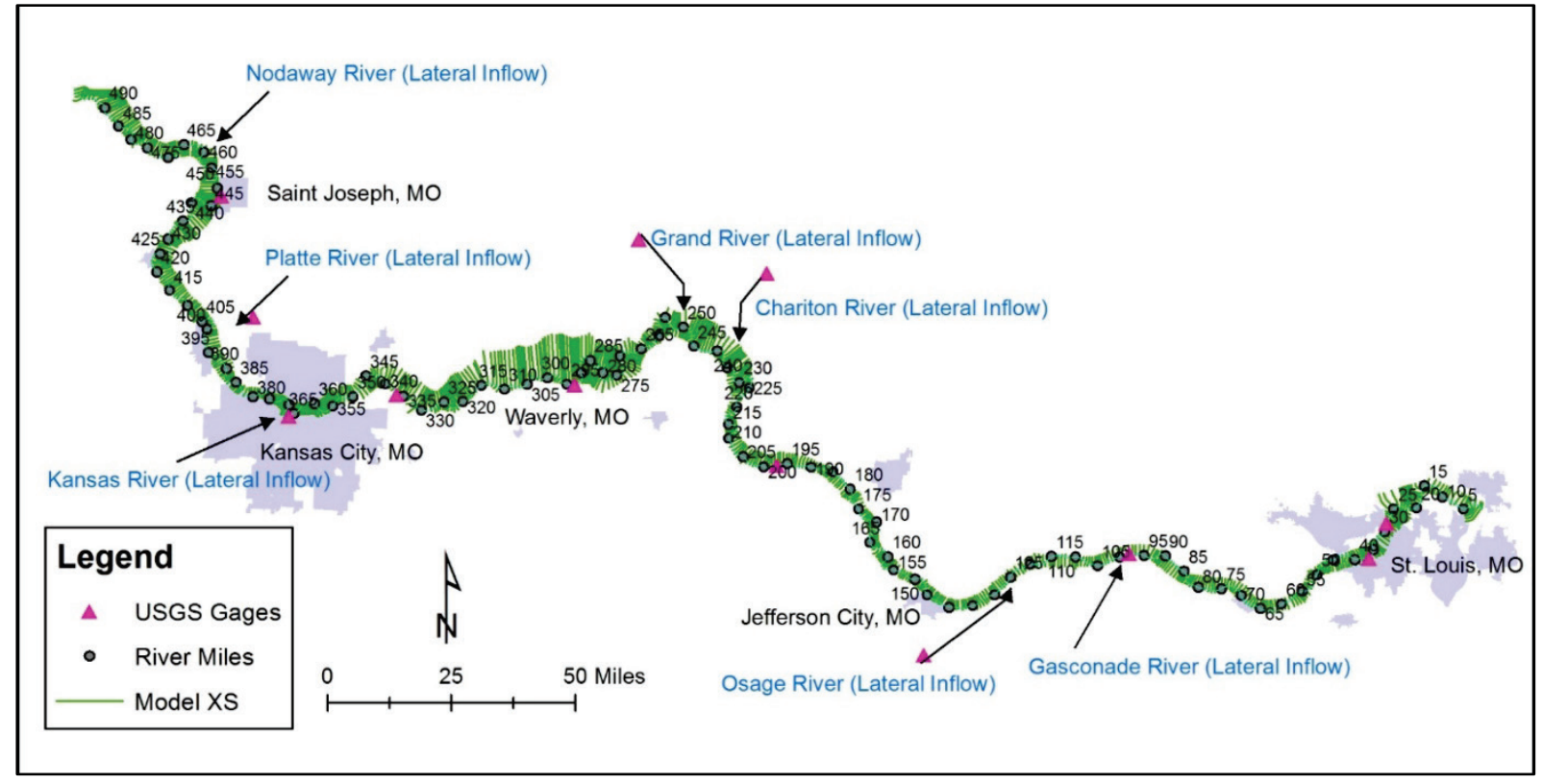

Figure 1. Model schematic.

The starting geometry was synthesized using bed bathymetry from the 1994 hydrographic survey data (USACE 1994) and bank and overbank data from 2013 LIDAR. Dike, sill, and revetment structures were entered into the cross sections as station/elevation points to account for the blocked flow area between dike structures. The methodology is similar, but more robust, to that used on the Missouri River by Teal and Remus (2001) and in USACE (2017). Conceptually, the ineffective flow areas within each control volume are summed, then divided by the control volume length to compute the blocked area to be entered into each cross section.

Bed gradations, flows, sediment loads, temperature, and downstream water surface were based on measured values, as described in USACE (2018a). The model also includes channel mining at the locations, dates, and quantities described in historical records over the calibration period (1994 to 2014).

The model was calibrated from 1994 to 2014 using multiple hydraulic and sediment metrics including a low-water profile collected in 1994, daily water surface elevations at six gages from 1994 to 2014, acoustic Doppler current profiler measurements collected during and after the Missouri River flood of 2011, USGS annual sediment loads at three gages, bed elevation change at thousands of cross sections, and longitudinal cumulative mass change over two time periods (1994 to 2009 and 2009 to 2014).

This MRRP model was updated for use in HEC-RAS 5.0.7, which necessitated slight recalibration of parameters. Figure 2 provides the longitudinal cumulative volume calibration from 1994 to 2009. A full description of all the calibration metrics is documented in USACE (2019). 


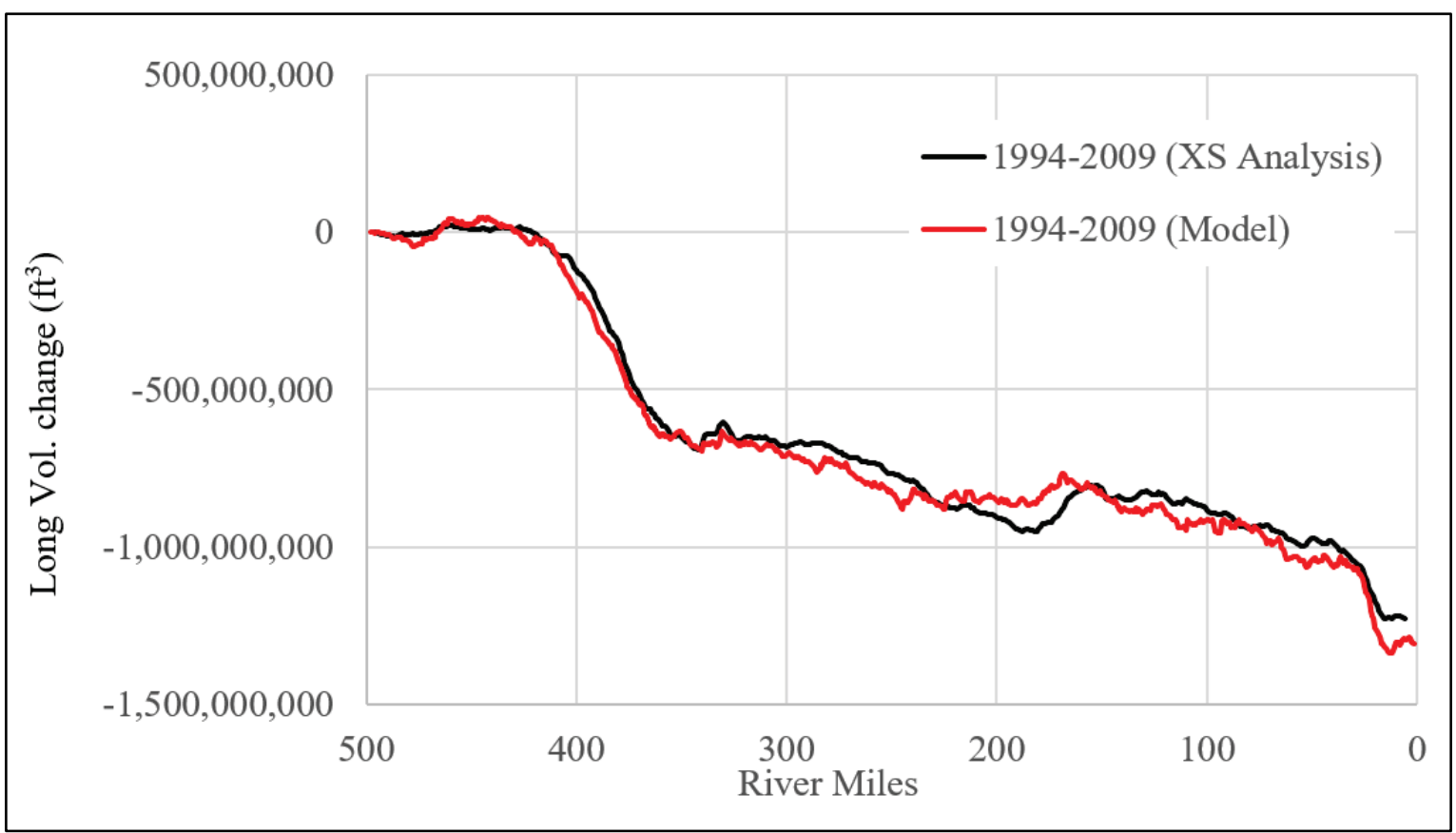

Figure 2. Longitudinal cumulative mass calibration: 1994 to 2009.

Model bathymetric data were updated to a summer 2014 hydrographic survey for use in making projections. A 40-year simulation was produced using the first 40 years of the 82-year period of record adjusted for current operational conditions, described in USACE (2018b). The channel mining condition for the future simulation is the currently permitted amount, as specified in USACE (2018a) repeated each year for 40 years. This projection does not include any regulatory actions to restrict channel mining when permitted degradation thresholds are exceeded. The actual bed elevations experienced in the future will depend on the actual flows and channel mining amounts and locations, which will differ from those presented here.

MODEL RESULTS: The 40-year simulation was run four times, with base-case sediment loads and with sediment loads set to $105 \%, 125 \%$, and $150 \%$ of the base case. No other parameters were changed. Table 1 provides the total volume of sediment entering the model domain at Rulo, Nebraska, and the total volume of bed change for each scenario.

\begin{tabular}{||l|l|l|l||}
\hline \hline \multicolumn{5}{||l}{ Table 1. Sediment volumes. } \\
\hline \hline Scenario & $\begin{array}{l}\text { Sediment Inflow } \\
\text { (tons/year) }\end{array}$ & $\begin{array}{l}\text { Increase from Base } \\
\text { Case (tons/year) }\end{array}$ & $\begin{array}{l}\text { Increase from Base } \\
\text { Case (ft } 3 \text { /year) }\end{array}$ \\
\hline Base Case & $4,876,509$ & NA & NA \\
\hline$+5 \%$ & $5,120,334$ & 243,825 & $5,243,558$ \\
\hline$+25 \%$ & $5,364,160$ & $1,219,127$ & $26,217,789$ \\
\hline$+50 \%$ & $7,314,763$ & $2,438,254$ & $52,435,578$ \\
\hline
\end{tabular}


Figure 3 provides the mean effective invert change for each scenario. As seen, while significant variability exists in the mean effective invert change, the river is generally degradational under all scenarios.

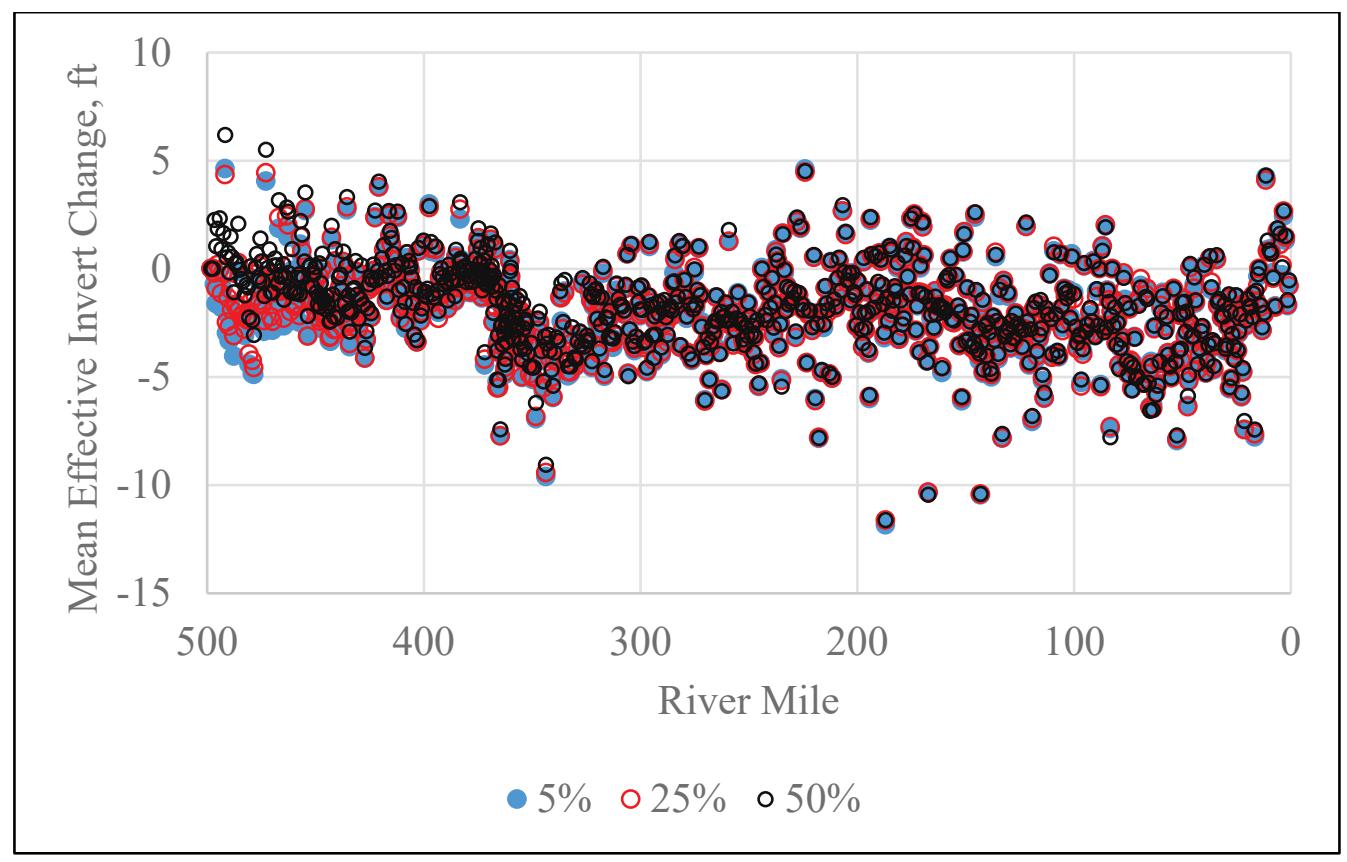

Figure 3. Mean effective invert change at the end of 20 -year simulation with incoming sediment loads varying from $100 \%$ to $150 \%$ of the base case.

Figures 4 and 5 isolate the effect of the sediment increase by presenting the departure in the mean effective invert change of a given scenario from the base case. As seen, an increase in sediment load of 5\% (4.4 million $\mathrm{ft}^{3} /$ year) results in very little change anywhere. At higher increases, the effect is increased deposition near the end of the model domain that tapers off to a less than $0.5 \mathrm{ft}$ rise by approximately RM 415. The effect is slightly more pronounced between RM 370 and RM 340, which coincides with the highly degraded Kansas City area. By RM 250, all scenarios have collapsed to the base case and are within the model noise. 


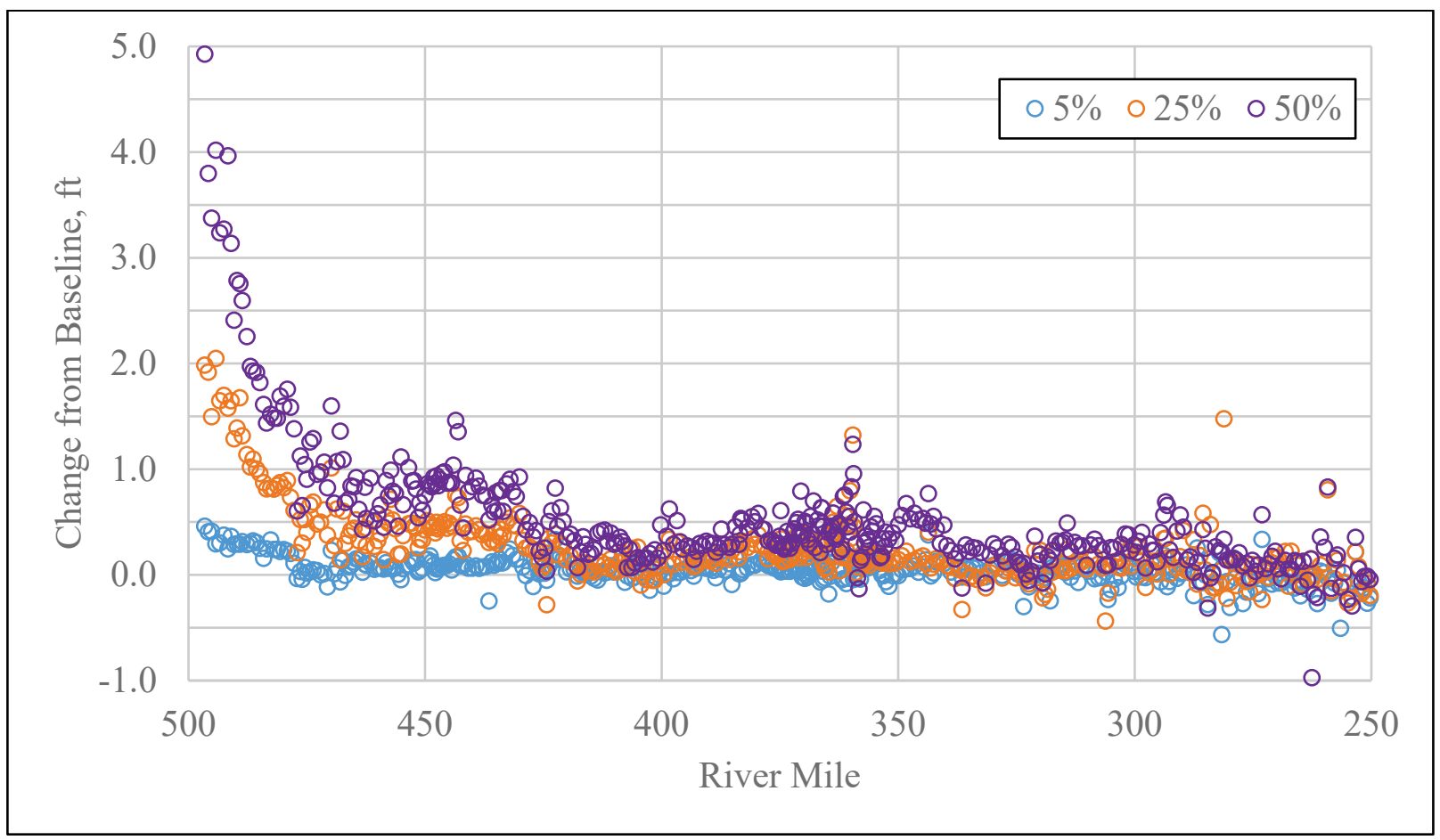

Figure 4. Departure of mean effective invert from the base case after 20 years: RM 500-RM 250.

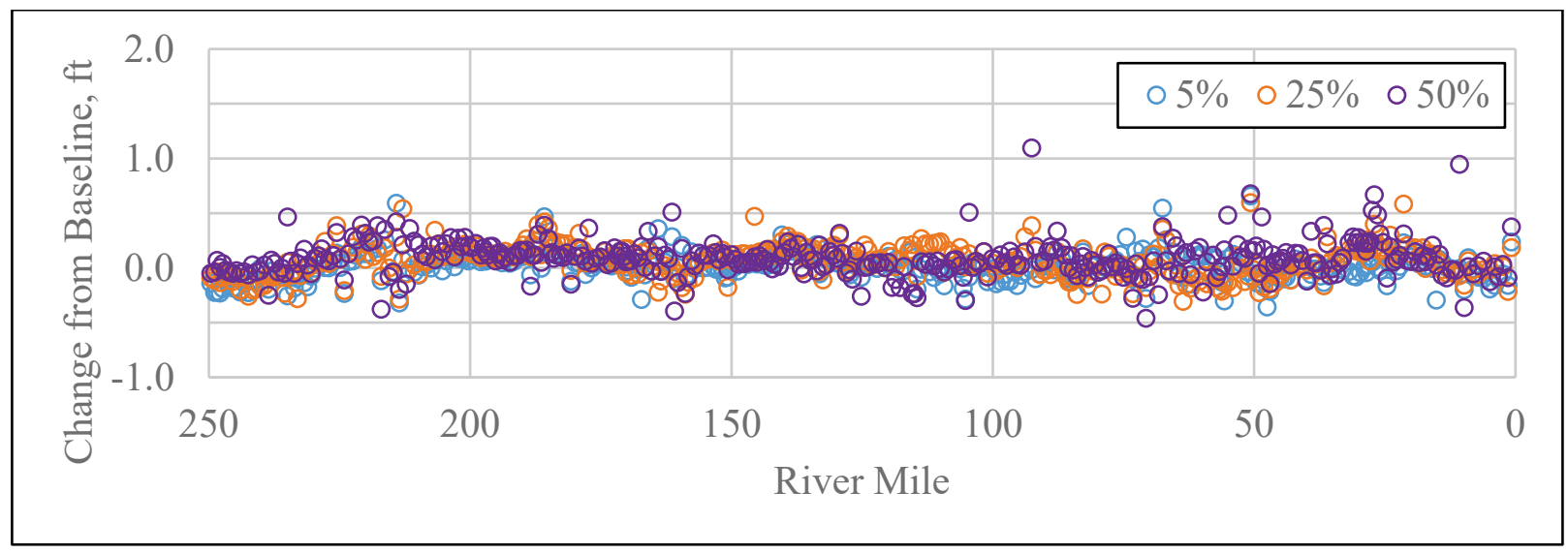

Figure 5. Departure of mean effective invert from the base case after 20 years: RM 250-RM 0.

Figures 6 and 7 provide the departure from the Base Case after 40 years of simulation. The zone of significant depositional effect has migrated downstream, tapering down to $0.5 \mathrm{ft}$ by approximately RM 410. The area of bed recovery centered on Kansas City has expanded from approximately RM 400 to RM 310. Even after 40 years, the bed downstream of RM 250 is largely unaffected. 


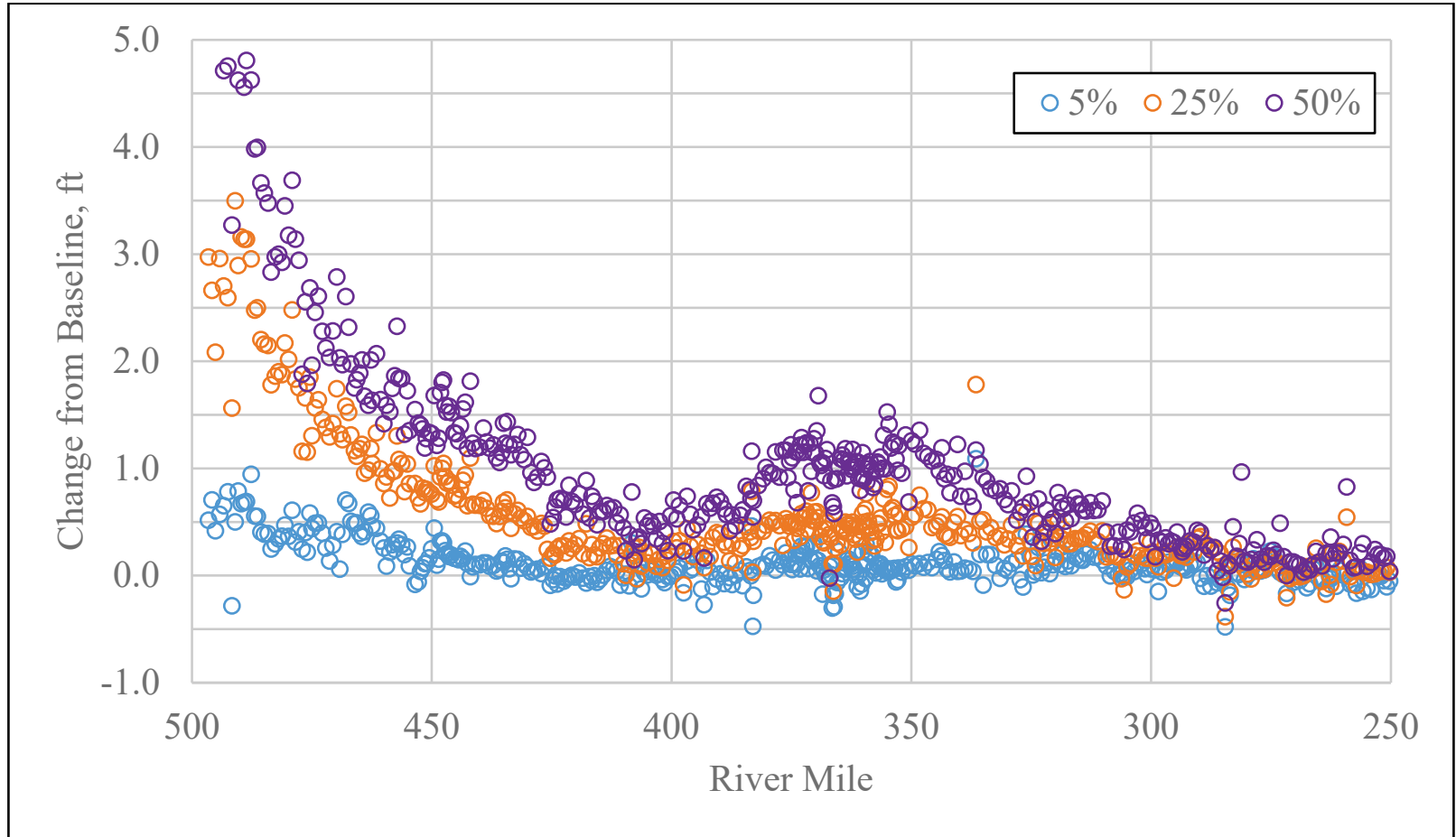

Figure 6. Departure of mean effective invert from the base case after 40 years: RM 500-RM 250.

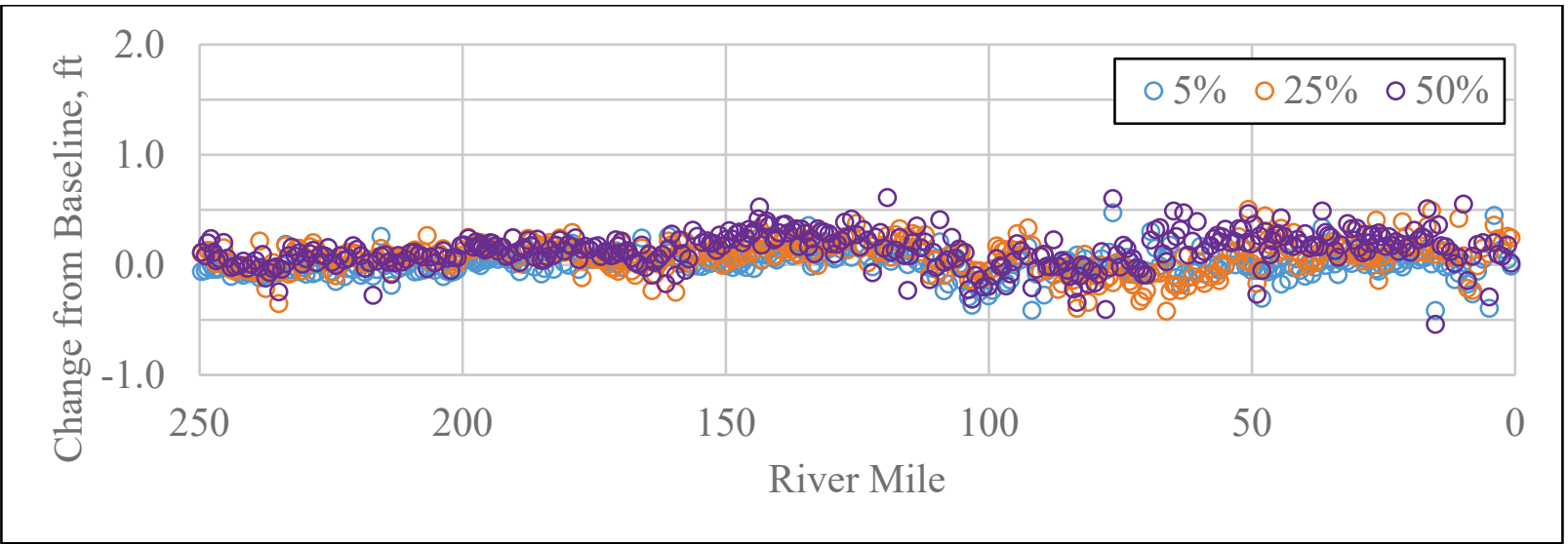

Figure 7. Departure of mean effective invert from the base case after 40 years: RM 250-RM 0.

Figure 8 compares the deposition from a 50\% increase in sediment load after 20 years and after 40 years. As seen, the deposition traveled approximately 30 miles in the first 20 years and migrated downstream an additional 15 miles in the next 20 years. 


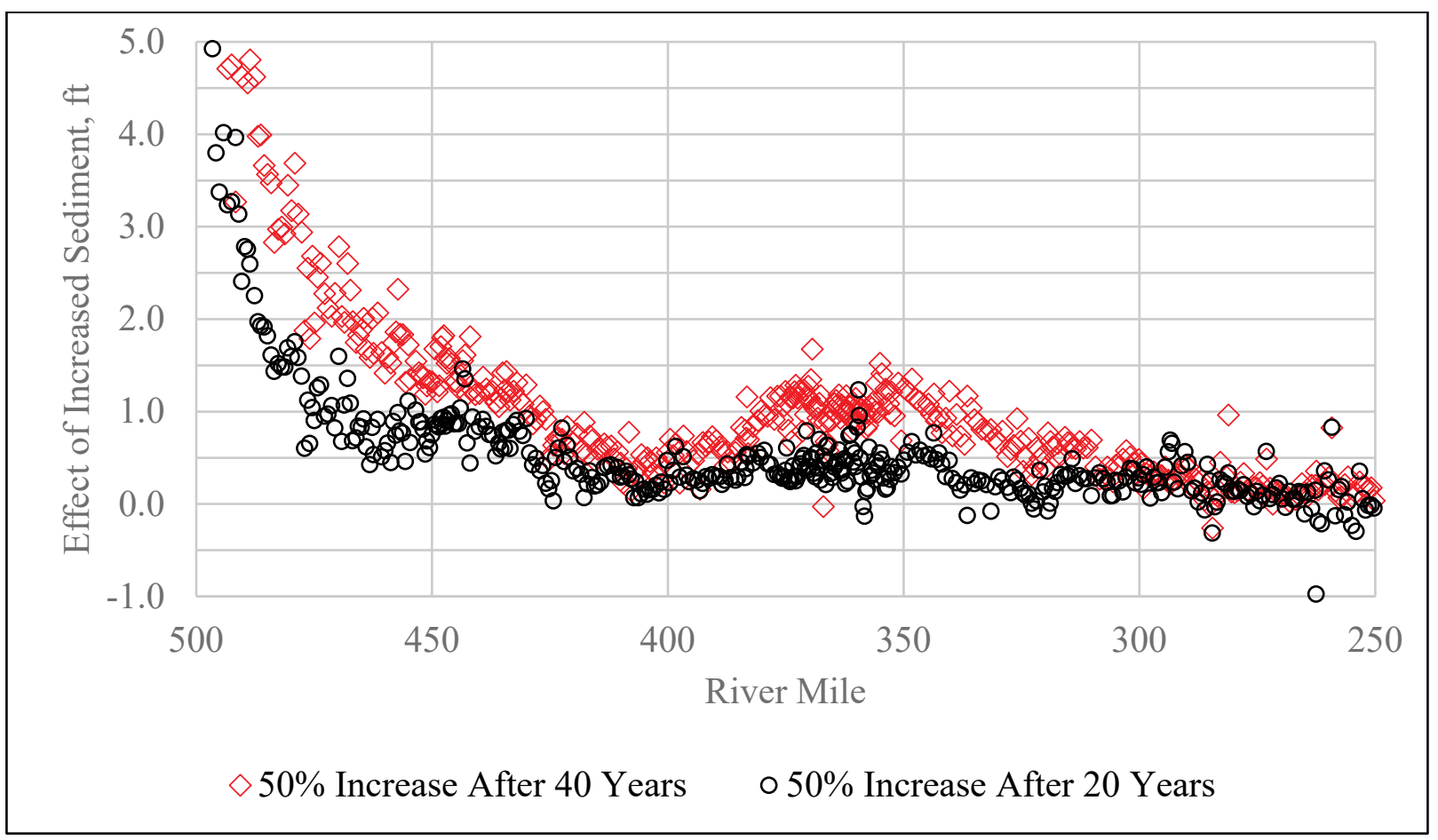

Figure 8. Comparison of deposition after 20 years and 40 years.

DISCUSSION: These analyses demonstrated that an increased sediment load at Rulo, Nebraska, can lead to increases in bed elevation (which for a degrading river equates to less bed degradation) in the Lower Missouri River. The changes were most pronounced near RM 498 and have completely disappeared by RM 250. The downstream migration rate of the most pronounced deposition ranged from 0.75 to 1.5 miles/year.

While the rate of geomorphic change in the upper river may well be different than in the Lower Missouri River for equivalent sediment increases, approximating the time it could take increased sediment loads from Gavin's Point Dam to reach Rulo, Nebraska, is instructive. Gavin's Point dam is located at RM 811, which is 313 miles upstream of Rulo, Nebraska. At 1.5 miles/year, it would take 209 years for the sediment to cause significant deposition (or reverse degradation) at Rulo, Nebraska. However, as seen by the deposition in Kansas City, it may be possible that highly degraded areas of the river could benefit sooner from additional sediment.

ADDITIONAL INFORMATION: The sediment model used for this analysis was originally created by Dr. John Shelley, USACE Kansas City District, and Dr. Stanford Gibson, USACE Institute for Water Resources Hydrologic Engineering Center using funds from the MRRP. The analysis presented in this RSM-TN was funded by the USACE National Regional Sediment Management (RSM) program, a Navigation Research, Development, and Technology Transfer portfolio program administered by Headquarters, USACE. For information on the RSM program, please consult http://rsm.usace.army.mil or contact the USACE National RSM Program Manager, Katie Brutsché, Katherine.E.Brutsche@erdc.dren.mil. For information regarding this RSM-TN, please contact John Shelley, John.Shelley@usace.army.mil. 
This RSM-TN should be cited as follows:

Shelley, John. 2021. Modeling the Effect of Increased Sediment Loading on Bed Elevations of the Lower Missouri River. ERDC/TN RSM-21-2. Vicksburg, MS: US Army Engineer Research and Development Center. http://dx.doi.org/10.21079/11681/40360

\section{REFERENCES}

Teal, M., and J. Remus. 2001. Lake Sharpe Sediment Flushing Analyses. World Water and Environmental Resources Congress. May 20 - 24, 2011. Orlando, FL.

USACE (US Army Corps of Engineers). 1994. Missouri River Hydrographic Survey: Rulo, Nebraska to the Mouth. Kansas City, MO: US Army Corps of Engineers, Kansas City District.

USACE. 2013. Lewis and Clark Lake Sediment Management Study. Part I: Summary Report on Evaluating Hydraulic Transport of Missouri River Delta Sediments. Omaha, NE: US Army Corps of Engineers, Omaha District.

USACE. 2017. Missouri River Bed Degradation Feasibility Study Technical Report. Kansas City, MO: US Army Corps of Engineers, Kansas City District.

USACE. 2018a. Missouri River Recovery Program Management Plan, Lower Missouri River Sediment Model Calibration Report. Kansas City, MO: US Army Corps of Engineers, Kansas City District.

USACE. 2018b. Missouri River Recovery Program Management Plan, HEC-RAS Model Calibration Report. Appendix E. Kansas City, MO: US Army Corps of Engineers, Kansas City District.

USFWS (US Fish and Wildlife Service). 2000. Biological Opinion on the Operation of the Missouri River Main Stem Reservoir System, Operation and Maintenance of the Missouri river Bank Stabilization and Navigation Project, and Operation of the Kansas River Reservoir System. Washington, DC: US Fish and Wildlife Service.

USFWS. 2003. US Fish and Wildlife Service 2003 Amendment to the 2000 Biological Opinion on the Operation of the Missouri River Main Stem Reservoir System, Operation and Maintenance of the Missouri River Bank Stabilization and Navigation Project, and Operation of the Kansas River Reservoir System. Washington, DC: US Fish and Wildlife Service.

NOTE: The contents of this technical note are not to be used for advertising, publication, or promotional purposes. Citation of trade names does not constitute an official endorsement or approval of the use of such products. 